\title{
Additional Income : Concepts and Efforts in Improving Motivation of Employment Civil Services as Step to Make Agood Governance
}

\section{Ichsandria Erdinal}

Universitas Negeri Padang, Padang - Indonesia, (ichsandriaerdinal@gmail.com)

\begin{abstract}
The rapid development in the era of globalization and complex problems faced by the State in line with the development of governance to realize good governance. Good governance is a prerequisite to realize the desire of the community in achieving the goals of nation and state. Implementation of the concept of good governance has its own challenges, for it needed resources apparatus that have competence in running government administration and sustainable development. To create competent apparatus that is efficient, effective, clean, strong and authoritative and able to carry out general duties of government and development as well as possible, it is necessary to improve quality and work motivation. In order to improve the quality and motivation of work it is necessary to provide additional income employee to Civil State Apparatus.
\end{abstract}

Keywords: additional income, good governance, state civil apparatus, work motivation.

\section{Introduction}

The role of government cannot be separated from the pulse of the life of the nationand state(Fabricius, 2004; Mufiz, 2014; Wight, 2002), in the process State Civil Apparatus is prepared to run the wheels of government as its essence(Majchrzak \& Markus, 2013; Pola, Da Lengkong, \& Londa, 2017; RINALDI, 2016). Globalization era is bringing positive impacts(Scholte, 2005; WINDIANI, 2013) and demands to ASN to improve the quality, both in terms of government administration and development in order to create good governance or Good Governance(Daryanto, 2007; Hawkins \& Parkhurst, 2016; Nganga \& Kambutu, 2017). The realization of good governance is a prerequisite to realize the aspirations of society in achieving the goals of the nation and the State(Ali, 2015; Lukow, 2013; Manuel Galvin Arribas, 20s16; Samin, 2011).

Good governance is a process of governance in order to apply good governance and services (public good and services), or commonly referred to as governance (governance or governance), while in best practice is called "good governance" (Mungiu-Pippidi, 2015; Pagallo, 2015; Wiranta, 2015).

Implementation of the concept of good governance has its own challenges(Fung, 2015), for it needed resources apparatus who have competence in the implementation of the State and 
development(Brinkerhoff \& Brinkerhoff, 2015). The existence of human resources within a government agency plays a very important role. Labor has great potential to run government activities. Potential of every human resources that exist in government agencies should be utilized with the best possible so as to provide optimal results of work. Achieving the goals set by a government agency depends not only on modern equipment, facilities and complete infrastructure, but rather more dependent on employees/apparatus that carry out the work(Moynihan \& Kroll, 2016; Salamah \& Rustiana, 2017).. To achieve maximum results, local government as the organizer of government affairs must be able to process and implement rights and obligations based on good governance principles (Good Governance) in accordance with general principles of state administration.

The ASN in which there are Civil Servants and Government Employees with the Employment Agreement is a state servants and public servants need to continue to improve its service in order to create an efficient, effective, clean, strong and authoritative apparatus and capable of performing the duties general government and development as well as possible. In order to improve the quality and achievement it is necessary to increase the reward to maintain motivation, one of them additional income given to ASN(Madjid, 2016; Soetisna, Ayuningtyas, \& Misnaniarti, 2015).

Furthermore, as set forth in the Regulation of the Minister of Home Affairs of the Republic of Indonesia Number 13 Year 2006 regarding Regional Financial Management Article 39 Paragraph 2 that "Additional income is granted in the framework of improving the welfare of employees based on workload or place of duty or working conditions or scarcity of profession or work performance"(Yusrawati \& Andini, 2015). In the Regulation of the Minister of Home Affairs of the Republic of Indonesia it is clear that the purpose of providing additional income is in order to improve the welfare of employees / ASN based on workload or place of duty or working conditions or scarcity of profession or job performance.

It is mandated in Law Number 5 Year 2014 on the State Civil Apparatus that the government is obliged to pay a fair and proper salary to civil servants and ensure the welfare of civil servants. Components of salary received by civil servants consist of only 3 kinds of salary, performance allowances, and overpriced benefits(Yustisia, 2015).

\section{Public Policy}

Policy is an instrument of government(Feiock, Jeong, \& Kim, 2003), not only in the sense of government, (only concerning the state apparatus), but also the governance that touches various institutions, private sector, business world, and civil society . The policy is essentially a decision or choice of action that directly regulates the management and distribution of natural, financial, and human resources for the benefit of the public, ie, the people and citizens(Frederickson, Smith, Larimer, \& Licari, 2015; Hawkins \& Parkhurst, 2016).

Public policy occurs because of government actions in addressing problems arising in society resulting in decisions(Fung, 2015; Maharani, 2014). One of them is the decision regarding the provision of additional income. As stipulated in the Regulation of the Minister of Home Affairs of the Republic of Indonesia Number 13 Year 2006 regarding Regional Financial Management Article 39 Paragraph 2 that "Additional income is granted in the framework of improving the welfare of employees based on workload or place of duty or working conditions or scarcity of profession or work performance". The Regulation of the Minister of Home Affairs of the Republic of Indonesia is clear that the purpose of providing additional income is in order to improve the welfare of employees / ASN based on workload or place of duty or working conditions or scarcity of profession or work motivation.

\section{Good Governance}


Implementation of Good Governance is the main prerequisite for every governance in order to meet the aspirations of the people and achieve the goals and ideals of the nation and state(Bastian, 2014; Langelo, Saerang, \& Alexander, 2015). Good governance can be interpreted as an efficient public service, a reliable court system, a government accountable to the public(Bannister \& Connolly, 2014; Manossoh, 2015).

Understanding good governance is often interpreted as good governance (De Graaf \& Paanakker, 2015). Good governance is a trustworthy government effort and to create good governance the government needs to be decentralized and in line with the principles of clean governance and free of corruption, collusion and nepotism(Nasution, 2016).

Good governance is good governance in a business based on professional ethics in trying / working(Klettner, Clarke, \& Boersma, 2014). Understanding good governance is a form of acceptance of the importance of a set of rules or good governance to govern relationships, functions and interests of various parties in business and public service. Understanding of good governance is to create performance management excellence both in manufacturing business enterprises (good corporate governance) or service companies, and public service / government (good governance). Understanding good governance is a manifestation of respect for the system and good structure to manage the company with the aim of improving business productivity.

\section{EmployeeMotivation}

Motivation is an important instrument in maintaining work productivity of ASN, because motivation is a number of processes that are internal or external to the individual that causes enthusiasm and persistence in the right to do certain activities (Gray, Javad, Power, \& Sinclair, 2001). Keeping ASN Motivation necessary because it is as a stimulus in the work. ASN will work with all forms of capabilities it has if there is a goal. In the work environment, motivation also influences the performance results either positively or negatively(Malik, Butt, \& Choi, 2015; Sriwidodo \& Haryanto, 2010). If employees have good work motivation, in general will be able to do a good job as well.

Provision of motivation is one of the goals for ASN who are given the motivation to work in accordance with the reference work and responsibility given so that organizational goals can be achieved properly. In addition, there are also elements of efforts, namely efforts that are qualified and directed and consistent with the goals of the organization to be achieved (Murty \& Hudiwinarsih, 2012). Provision of motivation can be in the form of financial motivation, namely encouragement made by providing financial rewards to employees. The reward is often called an incentive or in practice in the world of bureaucracy is Additional Income Employees.

\section{Additional Income}

The application of additional incomeis one way that the government does in developing regional development (Rai, 2008). The application of additional income of Civil Servants is one of them. Additional incomeis one of the important elements in work relations and development achievement.

Additional income enforcement is part of the bureaucratic reform policy to encourage accelerated changes in the performance improvement of government employees(Kadarisman, 2011; Uguy \& Achayat, 2012). Government employees as a government tool are required to work more professionally, morally, cleanly and ethically in support of bureaucratic reform and support the smoothness of government duties and development.

Additional income for government officials is motivated by the awareness as well as the government's commitment to realize good governance, because changes and renewals implemented in order to realize clean and authoritative governance is unlikely to be implemented properly (effectively) without the proper welfare of employees who carry it out (Maharani, 2014). Thus, it can be said that additional incomeis a motivational tool that encourages employees to work with the 
optimal ability, which is meant as extra income outside of salary or wage that has been determined. The granting of additional incomeis intended to meet the needs of employees and their families.

Additional incomemay be formulated as an adequate remuneration to employees whose performance exceeds the established standard. Additional incomeis a driving factor for employees to work better in order to improve employee performance. additional incomeis used to encourage employees to improve the quality and quantity of their work and to encourage employees to perform their duties properly in the form of financial incentives to employees as a reward for the employee to the employee's performance (Murty \& Hudiwinarsih, 2012).

Thus it can be concluded that one way to improve the quality of service is to provide additional income system that can improve employee work motivation.

\section{Purposes of Additional Income}

The purpose of giving additional income is divided into two group (Hasibuan, 2008):

a. For the Organization

The purpose of the implementation of additional incomein the organization especially in production activities is to improve employee work productivity by encouraging employees to work more excited and faster, work more disciplined and work more creatively

b. For Employees

With the additional incomethe employee will benefit in the form of achievement standards can be measured quantitatively, achievement standards can be used as the basis of reward measured in the form of money and employees must be more active in order to receive a greater income

Additional income given to civil servants is stimulation for the development and improvement of their performance, because in the organization of State role and position of civil servant is very strategic. Civil servants are elements of the State Apparatus who are tasked to provide services to the community professionally, honestly, fairly and equally in the implementation of the task of the State, government, and development. The smooth implementation of government and national development depends mainly on the perfection of the State Apparatus and the perfection of the State Apparatus depending on the perfection of civil servants. Provision of additional income is intended to meet the needs of employees, with the fulfillment of these needs are expected employees can work better, faster and in accordance with company standards so that the output generated can increase rather than input and eventually the performance of employees can increase.

So the provision of additional incomeis a motivational tool that can stimulate or encourage employees in order to generate greater enthusiasm for achievement for performance improvement.

\section{Indicator of Additional Income}

Some basic calculation or consideration of additional income preparation (Schermerhorn, et al., 2014):

a. Performance

The additional incomesystem in this way directly attributes the size of the additional income to the work that the employee has indicated. Means the size of the additional income depends on the small number of results achieved in the employee's time. It can be argued that in this way it can encourage less productive employees to be more productive in their work. In addition it is also very profitable for employees who can work fast and highly capable.

b. Length of working

The amount of additional income is determined on the basis of the length of time employees perform or complete a job. The calculation can use per hour, per day, per week or per month. 
Generally the way in which there are difficulties in applying additional income based performance.

c. Seniority

the additional income system is based on the employment or seniority of the employees concerned in an organization. The rationale is that senior employees, indicating the high loyalty of the employees concerned in the organizations in which they work. The more senior an employee the higher his loyalty to the organization, and the more steady and calm within the organization. The obvious disadvantage of this method is not necessarily that these seniors have high or outstanding abilities, so it is likely that a prominent youth employee will be led by a senior employee, but does not stand out. They become leaders not because of his ability but because of his tenure. In such situations it can arise where the energetic and capable junior employees leave the company / agency.

d. Needs

This method indicates that the additional income on employees is based on the level of urgency of decent living needs of employees. It means that the additional income given is reasonable if it can be used to meet some basic needs, not excessive but not lacking. This allows employees to survive in the company / agency.

e. Justice and Feasibility

1) Justice.

In the additional income system is not necessarily equally indiscriminate, but must be related to the relationship between the sacrifice (input) with (output), the higher the higher the expected sacrifice of additional income, so that should be assessed is the sacrifice required by a position. The input of a position is indicated by the specification to be fulfilled by the person holding the position. Therefore, the higher the expected output. this output is shown by the additional income received by the employees concerned, where it contains a sense of justice that is highly regarded once by every employee of the additional income.

2) Feasibility

Besides the problem of justice in giving additional income it is also necessary to note the issue of feasibility. worthy of understanding comparing the amount of additional income with other companies engaged in similar business. if the additional income in the company concerned is lower than other companies, then the company / institution will get constraint that is the decrease of employee performance that can be known from various forms due to employee dissatisfaction about additional income.

f. Job Evaluation

Job evaluation is an attempt to determine and compare the value of a certain position with the value of other positions in an organization. This means also determining the relative value or price of a position to rank in determining the additional income.

\section{Conclusion}

Globalization era has brought positive impact and demands to ASN and Government Employee to improve quality, in terms of government administration and development in order to create good governance or Good Governance. The realization of good governance is a prerequisite to realize the aspirations of society in achieving the goals of the nation and the State. One way to improve quality is to provide additional income system that can increase employee work motivation.

\section{References}

Ali, M. (2015). Governance and good governance: A conceptual perspective. Dialogue (Pakistan), 10(1). 
Bannister, F., \& Connolly, R. (2014). ICT, public values and transformative government: A framework and programme for research. Government Information Quarterly, 31(1), 119-128.

Bastian, I. (2014). Akuntansi sektor publik.

Brinkerhoff, D. W., \& Brinkerhoff, J. M. (2015). Public sector management reform in developing countries: Perspectives beyond NPM orthodoxy. Public Administration and Development, 35(4), 222-237.

Daryanto, A. (2007). Merit system dalam manajemen Pegawai Negeri Sipil. Jurnal Kebijakan dan Manajemen PNS, 1(2), 1-10.

De Graaf, G., \& Paanakker, H. (2015). Good governance: Performance values and procedural values in conflict. The American Review of Public Administration, 45(6), 635-652.

Fabricius, C. (2004). The fundamentals of community-based natural resource management. Rights, resources and rural development: Community-based natural resource management in Southern Africa, 343.

Feiock, R. C., Jeong, M. G., \& Kim, J. (2003). Credible commitment and council-manager government: Implications for policy instrument choices. Public Administration Review, 63(5), 616-625.

Frederickson, H. G., Smith, K. B., Larimer, C. W., \& Licari, M. J. (2015). The public administration theory primer: Westview Press.

Fung, A. (2015). Putting the public back into governance: The challenges of citizen participation and its future. Public Administration Review, 75(4), 513-522.

Gray, R., Javad, M., Power, D. M., \& Sinclair, C. D. (2001). Social and environmental disclosure and corporate characteristics: A research note and extension. Journal of business finance $\mathcal{E}$ accounting, 28(3-4), 327-356.

Hasibuan, S. P. (2008). Manajemen Personalia. Bandung: Citra Aditya Bakti.

Hawkins, B., \& Parkhurst, J. (2016). The'good governance'of evidence in health policy. Evidence \& policy: a journal of research, debate and practice, 12(4), 575-592.

Kadarisman, M. (2011). Manajemen kompensasi.

Klettner, A., Clarke, T., \& Boersma, M. (2014). The governance of corporate sustainability: Empirical insights into the development, leadership and implementation of responsible business strategy. Journal of Business Ethics, 122(1), 145-165.

Langelo, F., Saerang, D. P. E., \& Alexander, S. W. (2015). Analisis penerapan standar akuntansi pemerintahan berbasis akrual dalam penyajian laporan keuangan pada pemerintah kota bitung. Jurnal EMBA: Jurnal Riset Ekonomi, Manajemen, Bisnis dan Akuntansi, 3(1).

Lukow, S. (2013). Eksistensi Good Governance Dalam Sistem Pemerintahan Daerah di Kota Manado. Jurnal Hukum Unsrat, 1(5), 130-142.

Madjid, M. (2016). Pengaruh Tambahan Penghasilan Pegawai (TPP) Dan Kemampuan Kerja Terhadap Kinerja Pegawai Pada Badan Perencanaan, Penelitian Dan Pembangunan Daerah (Bappeda) Kabupaten Morowali. Katalogis, 4(8).

Maharani, P. (2014). Pelaksanaan Pemberian Tunjangan Remunerasi dalam Menunjang Kinerja Pegawai Negeri Sipil di Kementrian Hukum dan HAM Kota Bandar Lampung. Jurnal Hima Han, 1(2).

Majchrzak, A., \& Markus, M. L. (2013). Methods for policy research: Taking socially responsible action (Vol. 3): Sage Publications.

Malik, M. A. R., Butt, A. N., \& Choi, J. N. (2015). Rewards and employee creative performance: Moderating effects of creative self-efficacy, reward importance, and locus of control. Journal of Organizational Behavior, 36(1), 59-74.

Manossoh, H. (2015). Implementasi Sistem Akuntansi Pemerintahan dalam Mewujudkan Good Government Governance pada Pemerintah Provinsi Sulawesi Utara. Jurnal Berkala Ilmiah Efisiensi, 15(5).

Manuel Galvin Arribas, J. (2016). Governance Dynamics and the Application of the Multilevel Governance Approach in Vocational Education and Training (VET) in the European 
Neighbourhood Countries: the case of the ENPI South region. European Journal of Education, 51(4), 495-512.

Moynihan, D. P., \& Kroll, A. (2016). Performance management routines that work? An early assessment of the GPRA Modernization Act. Public Administration Review, 76(2), 314-323.

Mufiz, A. (2014). Pengantar Ilmu Administrasi Negara. 1, 63.

Mungiu-Pippidi, A. (2015). The quest for good governance: how societies develop control of corruption: Cambridge University Press.

Murty, W. A., \& Hudiwinarsih, G. (2012). Pengaruh kompensasi, motivasi dan komitmen organisasional terhadap kinerja karyawan bagian akuntansi (studi kasus pada perusahaan manufaktur di Surabaya). The Indonesian Accounting Review, 2(02), 215-228.

Nasution, O. A. A. (2016). PENGARUH PELAKSANAAN PRINSIP-PRINSIP GOOD GOVERNANCE TERHADAP EFEKTIVITAS KERJA PEGAWAI KANTOR UNIT PELAYANAN TERPADU VI DINAS PENDAPATAN DAERAH KOTA MEDAN. PERSPEKTIF, 8(2).

Nganga, L., \& Kambutu, J. (2017). Preparing Teachers for a Globalized Era: An Examination of Teaching Practices in Kenya. Journal of Education and Practice, 8(6), 200-211.

Pagallo, U. (2015). Good onlife governance: On law, spontaneous orders, and design The Onlife Manifesto (pp. 161-177): Springer.

Pola, H., Da Lengkong, F., \& Londa, V. (2017). Kepemimpinan Camat Dalam Meningkatkan Prestasi Kerja Aparatur Sipil Negara Di Kecamatan Galela Barat. JURNAL ADMINISTRASI PUBLIK, $3(046)$.

Rai, I. G. A. (2008). Audit Kinerja pada Sektor Publik: konsep, praktik, studi kasus: Penerbit Salemba.

RINALDI, H. (2016). Perlindungan hukum tenaga honorer pada Pemerintahan Kota Padang pasca pelaksanaan undang-undang nomor 5 tahun 2014 tentang Aparatur Sipil Negara (Studi pada Badan Kepegawaian Daerah Kota Padang). Universitas Andalas.

Salamah, U., \& Rustiana, E. (2017). Meningkatkan mutu pelayanan medik melalui koordinasi antar unit dan profesionalisme petugas (Studi pada RSU Dr. Slamet-Garut). Jurnal Pembangunan dan Kebijakan Publik, 1(2), 38-47.

Samin, R. (2011). Reformasi birokrasi. Jurnal Fisip UMRAH, 2(2), 172-182.

Schermerhorn, J., Davidson, P., Poole, D., Woods, P., Simon, A., \& McBarron, E. (2014). Management: foundations and applications (2nd Asia-Pacific Edition): John Wiley \& Sons.

Scholte, J. A. (2005). Globalization: A critical introduction: Palgrave Macmillan.

Soetisna, T. W., Ayuningtyas, D., \& Misnaniarti, M. (2015). Penerapan Sistem Remunerasi dan Kinerja Pelayanan. Kesmas: National Public Health Journal, 10(1), 17-23.

Sriwidodo, U., \& Haryanto, A. B. (2010). Pengaruh Kompetensi, Motivasi, Komunikasi dan Kesejahteraan Terhadap Kinerja Pegawai Dinas Pendidikan. Jurnal Manajemen Sumber Daya Manusia, 4(1), 47-57.

Uguy, L. S., \& Achayat, A. P. (2012). Manajemen Sumber Daya Manusia.

Wight, P. A. (2002). Supporting the principles of sustainable development in tourism and ecotourism: government's potential role. Current Issues in Tourism, 5(3-4), 222-244.

Windiani, R. W. R. (2013). Politik Luar Negeri Indonesia dan Globalisasi. POLITIKA: Jurnal Ilmu Politik, 1(2), 88-98.

Wiranta, D. N. (2015). Transformasi Birokrasi: Cara untuk penguatan etika dan integritas dalam pencegahan korupsi. Jurnal Lingkar Widyaiswara, 2(4), 44-71.

Yusrawati, Y., \& Andini, D. (2015). Pengaruh kompetensi sumber daya manusia dan penerapan sistem akuntansi keuangan daerah terhadap kualitas laporan keuangan daerah. Jurnal Ekonomi KIAT, 24(1), 65-82.

Yustisia, T. V. (2015). Undang-Undang Nomor 5 Tahun 2004 tentang Aparatur Sipil Negara dan Peraturan Pemerintah tentang Kepegawaian Terbaru: VisiMedia. 